\title{
表面処理炭素材料によるホルムアルデヒド除去 ${ }^{\dagger}$
}

\author{
平田瑞穗・川崎直人・中村武夫 \\ 文榮龍馬・棚田成紀 \\ 近畿大学薬学部 桥 577-8502 大阪府東大阪市小若江 3-4-1 \\ （2003 年 2 月 21 日受付；2003 年 4 月 9 日掲載決定）
}

\section{Removal of Formaldehyde by Surface-modified Carbonaceous Materials}

\author{
Mizuho HiRata, Naohito Kawasaki, Takeo NaKamura, \\ Ryoma BUNEI and Seiki TANADA \\ School of Pharmaceutical Sciences, Kinki University \\ 3-4-1 Kowakae, Higashi-Osaka, Osaka 577-8502
}

(Received February 21, 2003 ; Accepted April 9, 2003)

\begin{abstract}
Recently, formaldehyde liberated from wallpapers, furnitures and adhesive agents in new buildings and houses cause troubles in human health, and this is called the sick building symdrome. In this study, the carbonaceous materials are prepared from coffee grounds by microwave treatment or by surface-treatments with two different silane coupling agents. We estimated the removal efficiency of formaldehyde by such materials. The water contents of coffee grounds are larger than those of other wastes and thus they were easily carbonized. Both the amount of formaldehyde adsorbed onto the carbonaceous materials and the adsorption rate increased with increasing microwave treatment period, and increased with increasing concentration of silane coupling agents, because the numbers of amino groups on the carbonaceous materials increase. The carbonaceous materials prepared from the coffee grounds would be utilized for adsorbates to remove formaldehyde.
\end{abstract}

\section{1. 緒}

\section{言}

近年，一般家屋やビルの高気密化，高断熱化および新 建材の開発が進んでおり, 新築住宅において室内環境問 題が生じている。つまり, 換気不足による室内空気污染 が原因となり, ヒトに対して様々な健康障害を引き起こ し，これはシックハウス症候群と呼ばれている11。特に, 建材, 塗料, 壁紙, 合板ボードなどに含まれるホルムア ルデヒドが室内空気中に揮発することが要因と考えられ ている。

大気中のホルムアルデヒドは, 地域や季節により変動 するが，職場，学校などにおけるその濃度基準は，0.08 ppm 以下であるが, 実際数〜十数 ppb 検出されている21。

†第 22 回表面科学講演大会 (2002 年 11 月 26 日〜 11 月 28 日) にて発表

E-mail: kawasaki@phar.kindai.ac.jp
発生源としては自動車排ガスや焼却炉があげられ, さら に光化学反応により生成する ${ }^{3)}$ 。家屋内においては, 主 に建材や家庭用品から放散されている。そこで, 室内污 染を予防するために, ホルムアルデヒドを含まない接着 剂の使用, 温度・湿度の管理, 換気などの対策が必要と なるが,これらの対策をしてもホルムアルデヒドが検出 されている。

一方，廃棄物を未利用資源とみなし，再資源化する技 術が開発されている。また, 食品廃棄物であるコーヒー 豆かすは, 日本において約 60 万トン/年排出されている。 しかし, 有機性廃棄物から吸着剂を製造する場合, 炭化 する必要があるが, コーヒー豆かすは水分含量が大きく, 従来のようにマッフル炬で炭化した場合, エネルギー効 率が悪くなる。一方, マイクロ波照射処理は, 含水状態 で高温となるため, 水分含量の高い廃棄物の炭化法とし て有益であると考えられる。 
最近，有害物質を濃縮し，酸化チタン（ $\mathrm{TiO}_{2}$ ) を用い た光触媒で分解することによる無害化法 ${ }^{4}$, 活性炭など の吸着剂による除去法などが検討されている。本論文で は, コーヒー豆かすから炭素材料を創製し，さらに，そ れらの表面処理を行い，それらのホルムアルデヒド除去 用吸着剂としての適用性を吸着量および吸着速度から評 価・検討した。

\section{2. 実 験 方 法}

\section{1 試料}

吸着質としてホルムアルデヒド溶液（和光純薬工業社 製), 吸着剂として市販の備長炭 (CH 1) および飲食店 から排出されたコーヒー豆かすを使用した。約 $65-70 \mathrm{~g}$ のコーヒー豆かすを周波数 $2,450 \mathrm{MHz}$, 出力 $500 \mathrm{~W}, 10-$ 20 分間マイクロ波照射処理し， 20-32 meshに揃え実験 に共した。未処理コーヒー豆かすを CG 0 とし, CG 0 を 10，15，20 分間マイクロ波照射処理した炭素材料を CG 10, CG 15, CG 20 とした。

\subsection{Sol-Gel 法による表面アミノ基の導入}

Sol-Gel 法は, 基板に機能性を賦与する方法として研

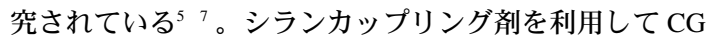
15 の表面改質を Sol-Gel 法により行った。今回, CG 15 表面にアミノ基を導入するため, アミノプロピルトリエ トキシシラン（チッソ社製：S 330）およびアミノエチ ルアミノプロピルメチルジメトキシシラン（チッソ社 製：S 310）を使用した。これらを $95 \%$ エタノール水溶 液に攪拌下に加え最終濃度が各々 $5,10,20,40 \%$ に なるように調製し, 加水分解とシラノール基生成のため に 5 分間静置した後, CG 15 約 $3.5 \mathrm{~g}$ を添加した。その 後 2 3 分間浸し, デカンテーションにより炭素材料を 分取し, エタノールで 2 回洗浄後, 約 $100^{\circ} \mathrm{C}$ で 24 時間 乾燥させた。

\section{3 炭素材料の比表面積および表面極性}

炭素材料の比表面積は FlowSorb II 2300 （micromeritics 社製）により測定した。試料は, $190^{\circ} \mathrm{C}$ で 3 時間真空脱 気したものを用いた。炭素材料の酸・塩基消費量は Bohem およびVoll の方法 ${ }^{8,9}$ に準じて測定した。すなわち, 酸消費量は $0.1 \mathrm{~mol} / \mathrm{L}$ 塩酸水溶液 $50 \mathrm{~mL}$ に精秤した約 $0.1 \mathrm{~g}$ の炭素材料を添加し, $25^{\circ} \mathrm{C}$ で 48 時間振り混ぜた 後, 吸着剂をろ別し, 万液 $50 \mathrm{~mL}$ を $0.1 \mathrm{~mol} / \mathrm{L}$ 水酸化ナ トリウム水溶液で逆滴定することにより求めた（指示 薬：フェノールフタレイン)。塩基消費量は $0.1 \mathrm{~mol} / \mathrm{L}$ 水酸化ナトリウム水溶液 $50 \mathrm{~mL}$ に約 $0.1 \mathrm{~g}$ 精秤した炭素 材料を添加し, $25^{\circ} \mathrm{C}$ で 48 時間振り混ぜた後, 吸着剤を ろ別し, 万液 $50 \mathrm{~mL}$ を $0.1 \mathrm{~mol} / \mathrm{L}$ 塩酸水溶液で逆滴定す ることにより求めた（指示薬：メチルレッド）。

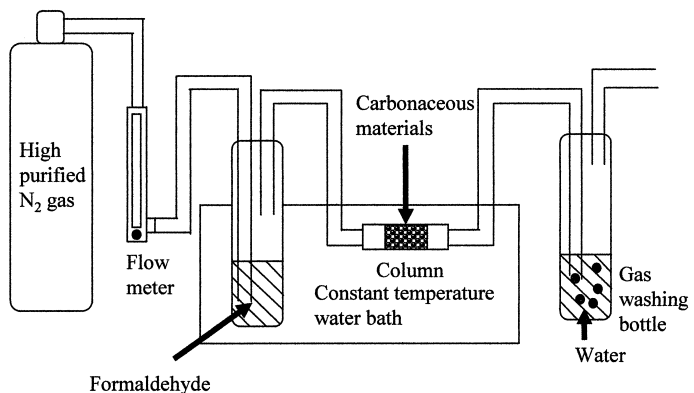

Fig. 1 Apparatus for formaldehyde adsorption measurements.

\section{4 炭素材料のホルムアルデヒド飽和吸着量}

炭素材料を正確に $0.1 \mathrm{~g}$ 秤量瓶に量りとり, ホルムア ルデヒド溶液と共にデシケータ内に入れ， $15^{\circ} \mathrm{C}$ および $25^{\circ} \mathrm{C}$ の恒温槽中で 72 時間静置後, 秤量し単位重量当り の飽和吸着量を算出した。

\section{5 炭素材料に対するホルムアルデヒド吸着速度} $300 \mathrm{~mL}$ 市ノ瀬氏式洗滌瓶にホルムアルデヒド溶液を 入れ，窒素ガスを流通させ，ホルムアルデヒド吸着装置 を組立てた（Fig. 1)。これに長さ約 $6 \mathrm{~cm}$ のカラムに炭 素材料を秤量・充填し, $25^{\circ} \mathrm{C}$ の恒温槽中でホルムアル デヒドを流入後, 炭素材料へ未吸着のホルムアルデヒド 流出量を 2 分ごとに測定した。ホルムアルデヒド流入量 および流出量の差から各々の時間における炭素材料への ホルムアルデヒド吸着量を算出した。ホルムアルデヒド の定量は 4-アミノ-3-ヒドラジノ-5-メルカプト-1,2,4-ト

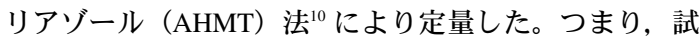
料溶液 $2.0 \mathrm{~mL}$ を試験管にとり, $5 \mathrm{~mol} / \mathrm{L} \mathrm{KOH}$ 溶液 2.0 $\mathrm{mL}$ および $\mathrm{AHMT}$ 溶液 $2.0 \mathrm{~mL}$ を加え, 室温で 20 分間放 置した。次に $\mathrm{KIO}_{4}$ 溶液 $2.0 \mathrm{~mL}$ を加え, 波長 $550 \mathrm{~nm}$ の 吸光度を測定し, 検量線より試料中のホルムアルデヒド 濃度を算出した。

\section{3. 結果と考察}

\section{1 炭素材料の諸物性}

最初に，マイクロ波照射処理による炭素材料製造法お よびマッフル炉を用いた製造法の消費電力を比較した。 マッフル炉を用いコーヒー豆かす由来炭素材料を温度 $800^{\circ} \mathrm{C}$ ，処理時間 150 分の条件で製造した場合，炭化収 率は $24.3 \%$ であり，一方，マイクロ波照射により出力 $500 \mathrm{~W}$ ，処理時間 10 分の条件で炭素材料を製造した場 合，炭化収率は $25.5 \%$ であった。両炭素材料とも炭化 収率はほぼ同程度であったが，製造時に必要な電力は， マッフル炬の場合 $3,750 \mathrm{Wh}$ であり，マイクロ波照射の 場合 $83 \mathrm{Wh}$ となった。さらに，マッフル炉により炭化 
した場合，炭化時間が長く窒素雾囲気下で行う必要があ った。この結果より, マイクロ波照射処理によるコーヒ 一豆かすの炭化は, 従来のマッフル炬による炭化法に比 ベ二酸化炭素排出を抑制できること, 炭素材料製造エネ ルギーを削減できることが示唆された。

炭素材料の表面化学的性質である酸・塩基消費量およ び炭化収率を Table 1 に示した。また, 物理的性質であ る比表面積と元素分析の測定結果を Table 2 に示した。 $\mathrm{CG} 10$ の酸消費量は最も低い值を示し, CG $0<\mathrm{CG} 15<$ CG 20 の順に増大した。Sol-Gel 法によりアミノ基を導 入した炭素材料の酸消費量はすべて CG 15 に比べ高值 を示し, S 310 (40％）が最も高い值を示した。CH 1 の 酸消費量は $5.4 \mathrm{mmol} / \mathrm{g}$ でほぼ中間值を示した。塩基消 費量については CG 0 が最大值を示し, CH 1 の值に比べ 約 2 倍となった。CH 1 は酸・塩基消費量ともほぼ同值 を示したが, S 310 (40％) を除く全ての炭素材料は, 酸消費量に比べ塩基消費量の方が高い值を示した。酸・ 塩基消費量は炭素材料表面に存在する官能基量の指標と なり, 酸消費量はアミノ基数, 塩基消費量はフェノール 性水酸基およびカルボキシル基数に相当する ${ }^{111}$ 。したが って, 炭素材料の表面アミノ基数にほとんど差が認めら れず, 表面カルボキシル基およびフェノール性水酸基数

Table 1 Chemical property and yield of carbonaceous materials.

\begin{tabular}{lccc}
\hline \multirow{2}{*}{ Samples } & \multicolumn{2}{c}{ Consumptions (mmol/g) } & \multirow{2}{*}{ Yield (\%) } \\
\cline { 2 - 3 } & Base & Acid & \\
\hline CH 1 & 5.2 & 5.4 & - \\
CG 0 & 11.7 & 4.0 & - \\
CG 10 & 5.0 & 3.2 & 25.5 \\
CG 15 & 7.8 & 4.9 & 6.9 \\
CG 20 & 8.2 & 5.8 & 5.3 \\
S 330 (5\%) & 7.6 & 6.1 & - \\
S 310 (5\%) & 7.6 & 6.0 & - \\
S 310 (10\%) & 7.6 & 5.6 & - \\
S 310 (20\%) & 7.9 & 5.6 & - \\
S 310 $30 \%)$ & 6.3 & 6.8 & - \\
\hline
\end{tabular}

が異なることがわかった。

次に CG 10 の収率は $25.5 \%$ と最も高い值を示し, CG 15 およびCG 20 では $6.9 \%$ および $5.3 \%$ となり, マイ クロ波照射処理時間の増大に伴い炭素材料は減少した。 また, 元素分析を行った結果, N/C 值はマイクロ波照 射処理による差が認められず，表面改質したものはシラ ンカップリング剂濃度の増大に伴い N/C 值は増大した。 一方, $\mathrm{H} / \mathrm{C}$ 值はマイクロ波照射により減少し, N/C 值 と同様の傾向が認められた。これらのことより, コーヒ 一豆かす炭表面にアミノ基が導入されていることを確認 した。一方, CH 1 の比表面積が最も高い值を示し, コ 一ヒー豆かす由来炭素材料の比表面積は, 全て $1 \mathrm{~m}^{2} / \mathrm{g}$ 以下を示し, CG 20 および S 310 (40\%) で若干増大し た。したがって, 炭素材料表面のみが改質されているも のと考えられる。

\section{2 炭素材料へのホルムアルデヒドの飽和吸着量}

$25^{\circ} \mathrm{C}$ および $15^{\circ} \mathrm{C}$ における炭素材料へのホルムアルデ ヒドの飽和吸着量を Table 3 に示した。CH 1 のホルム アルデヒド飽和吸着量は, 最も低い值を示し, 市販の木 炭によるホルムアルデヒド除去能は低いことがわかる。 一方, コーヒー豆かす由来炭素材料の飽和吸着量は, マ イクロ波照射処理時間が長いものほど, また, シランカ ップリング剂濃度が高いものほど増加した。CG 20 およ びS $310 （ 40 \%$ ）への飽和吸着量は, CG 0 の值に比べ, それぞれ $151 \%$ および $155 \%$ となり, 製造した炭素材 料の中でホルムアルデヒド除去能が高くなった。このこ とは, 表面アミノ基数が多いこと, 比表面積が若干増大 していること, によると考えられる。CH 1 の比表面積 は CGに比べ大きく, CH 1 と CG 10, CG 15, CG 20 の 塩基消費量がほぼ同程度であったが, CH 1 へのホルム アルデヒド飽和吸着量に比べ CGへの吸着量が増大し た。その原因として, CH 1 の表面官能基は細孔内に存 在しているのに対し，CG の場合表面に存在しているた めと考えられる。一方, 他の炭素材料においては大差が 認められなかった。つまり, 20 分間マイクロ波照射処 理を行うことにより, コーヒー豆かすの細孔容積が増加

Table 2 Physical and chemical properties of carbonaceous materials.

\begin{tabular}{lcc}
\hline \multicolumn{1}{c}{ Samples } & N/C $(\%)$ & $\mathrm{H} / \mathrm{C}(\%)$ \\
\hline CG 0 & 4.3 & 12.6 \\
CG 15 & 4.5 & 4.5 \\
CG 20 & 4.1 & 2.6 \\
S $310(20 \%)$ & 6.4 & 6.6 \\
S 310(40\%) & 7.6 & 5.3 \\
\hline
\end{tabular}

\begin{tabular}{lc}
\hline \multicolumn{1}{c}{ Samples } & Specific surface area $\left(\mathrm{m}^{2} / \mathrm{g}\right)$ \\
\hline CH 1 & 30 \\
CG 0 & $<1$ \\
CG 15 & $<1$ \\
CG 20 & 5 \\
S 330 $(5 \%)$ & $<1$ \\
S 310 $35 \%)$ & $<1$ \\
S 310 $(20 \%)$ & $<1$ \\
S 310(40\%) & 6 \\
\hline
\end{tabular}


Table 3 Saturated amount of formaldehyde adsorbed onto carbonaceous materials.

\begin{tabular}{lrrr}
\hline \multirow{2}{*}{ Samples } & \multicolumn{2}{c}{ S.A.F $F^{\mathrm{a})}(\mathrm{mg} / \mathrm{g})$} & \\
\cline { 2 - 3 } & $25^{\circ} \mathrm{C}$ & $15^{\circ} \mathrm{C}$ & \\
\hline CH 1 & 76 & 26 & 34 \\
CG 0 & 278 & 256 & 92 \\
CG 10 & 256 & 249 & 97 \\
CG 15 & 298 & 211 & 71 \\
CG 20 & 418 & 263 & 63 \\
S 330 (5\%) & 208 & 77 & 37 \\
S 310 (5\%) & 236 & 101 & 43 \\
S 310 (10\%) & 249 & 99 & 40 \\
S 310 (20\%) & 294 & 122 & 41 \\
S 310 (40\%) & 430 & 151 & 35 \\
\hline
\end{tabular}

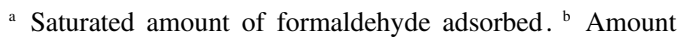
adsorbed at $15^{\circ} \mathrm{C} /$ amount adsorbed at $25^{\circ} \mathrm{C} \times 100$.

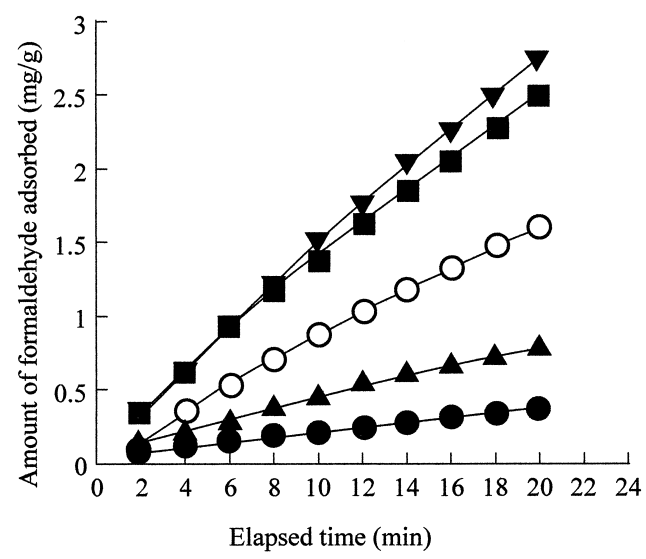

Fig. 2 Amount of formaldehyde adsorbed onto carbonaceous materials vs. elapsed time. 10, $\mathbf{\square}: \mathrm{CG} \mathrm{15,} \mathrm{\nabla :} \mathrm{CG} \mathrm{20,} \mathrm{О:} \mathrm{CH} 1$

することでホルムアルデヒド吸着量が増加し，さらに， 表面にアミノ基を導入することでも吸着量を増加させる

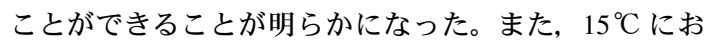
ける飽和吸着量は, $25^{\circ} \mathrm{C}$ のものに比べ低い值を示し, 特にシランカップリング剂で処理した場合, 約 $40 \%$ に まで減少した。

濃度の差によりホルムアルデヒド吸着能に差が認めら れた場合，実際の使用時に温度影響を受けやすくなるた め吸着剂として至適でない。Table 3 の結果より, マイ クロ波照射処理により調製された炭素材料への飽和吸着 量は, 温度の影響を受けにくく, シランカップリング剂 により表面アミノ基を導入した炭素材料は，その吸着機 構がアミノ基とホルムアルデヒドとの化学反応によるた め温度の影響を受けやすいことがわかる。これらの結果

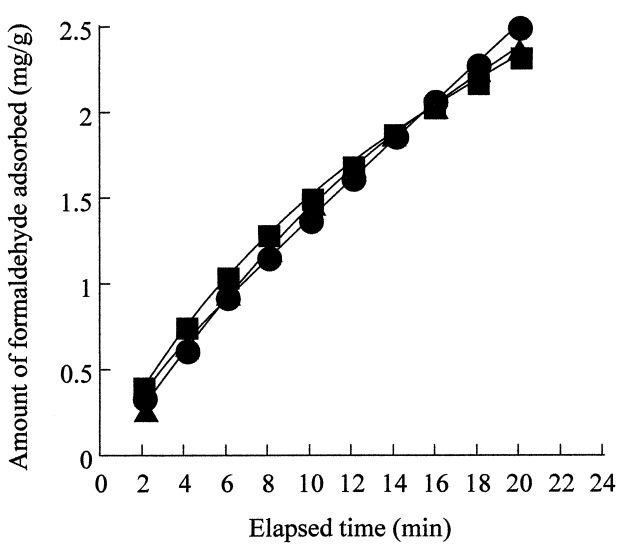

Fig. 3 Amount of formaldehyde adsorbed onto carbonaceous materials vs. elapsed time. $\mathrm{CG} 15, \boldsymbol{\Delta}$ : S $330(5 \%)$, $\mathbf{\square} 310(5 \%)$

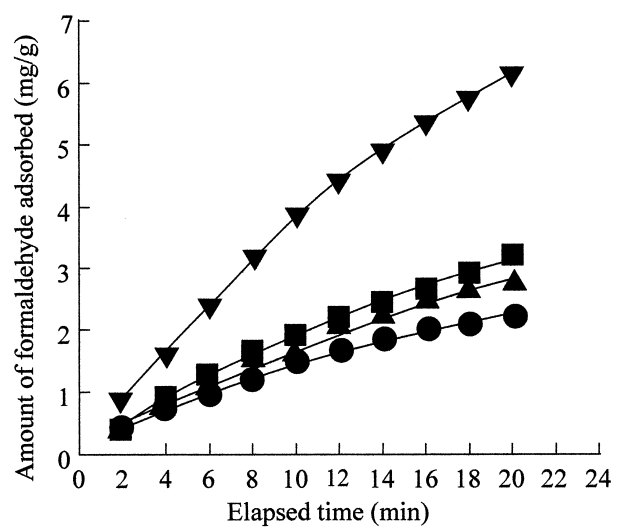

Fig. 4 Amount of formaldehyde adsorbed onto carbonaceous materials vs. elapsed time. : S 310(5\%), $\boldsymbol{\Delta}$ : S 310 (10\%), $\mathbf{\square}:$ S 310 (15\%), $\boldsymbol{\nabla}$ : S $310(20 \%)$

から，コーヒー豆かす由来炭素材料に対するホルムアル デヒドの吸着因子として物理的, 化学的因子が共に関与 していると推察された。

\section{3 炭素材料に対するホルムアルデヒド吸着速度} 吸着剤の有する吸着容量は, まず吸着平衡関係により その上限が決められるが, その容量をどのように活用す るかに関わるのは，その上限に達する速さである。実際 の吸着操作は必ず有限の時間内に行われるため, その吸 着速度を的確に評価する必要がある。Fig. 2-Fig. 4 にホ ルムアルデヒド吸着速度の時間変化を示した。Fig. 2 は マイクロ波照射処理時間の異なるコーヒー豆かす由来炭 素材料によるホルムアルデヒド吸着速度を示している。 この結果より, マイクロ波照射処理時間が長い炭素材料 においてホルムアルデヒド吸着速度が増大することがわ 


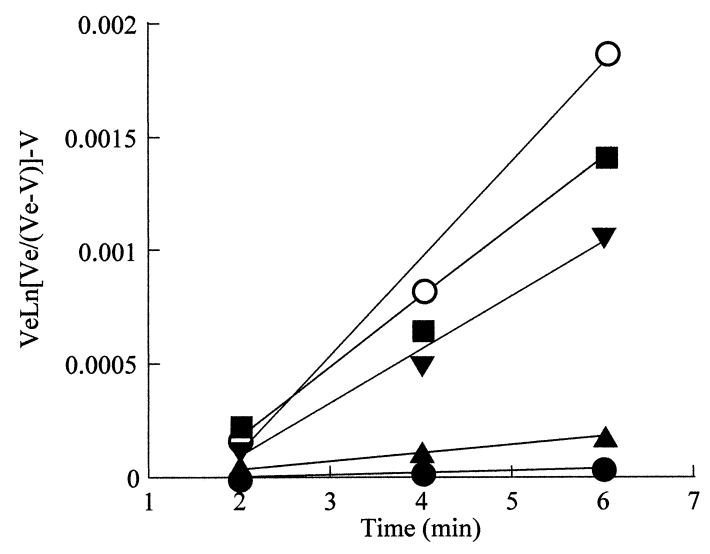

Fig. 5 Sameshima plots of adsorption data of formaldehyde onto carbonaceous materials. $\mathrm{EG} 0, \boldsymbol{\Delta}$ : CG 10, 口: CG 15, $\mathbf{\nabla}:$ CG 20, O: CH 1

かった。これは, 照射時間の増大に伴い, より炭素含量 が高く, 細孔容積が大きい吸着剤へと変化するためと考 えられる。Fig. 3 は異なる種類のシランカップリング剂 により調製した炭素材料への吸着速度を示している。こ の結果より, シランカップリング剂の種類による吸着速 度に大きな差は認められず, 濃度 $5 \%$ で調製した炭素 材料は, CG 15 と比べてほとんど差が認められなかった。 また, Fig. 4 は異なる濃度のシランカップリング剂によ り調製した炭素材料へのホルムアルデヒド吸着速度を示 している。この結果から, シランカップリング剂の濃度 を増大した炭素材料においてホルムアルデヒド吸着速度 が高い值を示し, 特に, $40 \%$ 以上の濃度で調製した場 合に有効であることがわかった。

次に, Fig. 2-Fig. 4 の結果を吸着速度式の 1 つである 鮫島式に適用した。鮫島式は Langmuir 吸着速度式より 導き出された式で低圧吸着初期においては次式で表され る12)。

$$
V e \cdot \operatorname{Ln}\{V e /(V e-V)\}-V=k t
$$

ここで $t$ は経過時間 $(\mathrm{min}), V e$ は飽和吸着量 $(\mathrm{mg} / \mathrm{g})$, $V$ は $t$ における吸着量 $(\mathrm{mg} / \mathrm{g}), k$ は吸着速度定数 $(\mathrm{mg} /$ $\mathrm{g} / \mathrm{min})$ である。鮫島式は, 縦軸に $V e \cdot L n\{V e /(V e-$ $V)\}-V$ を, 横軸に $t$ をプロットした直線であり, 定数 $k$ は, 回帰直線の傾きから算出される。Fig. 2-Fig. 4 の 結果を鮫島式に適用し, そのプロットを Fig. 5 および Fig. 6 に示した。その結果, 経過時間 6 分以内において, すべての炭素材料において直線となった。Fig. 5 および Fig. 6 の回帰直線の傾きから定数 $k$ を算出し, Table 4 に示した。CG 0 の定数 $k$ は最も低い值を示し, 一方, $\mathrm{CH} 1$ の定数 $k$ は 43 倍の速度となった。しかし, 飽和吸 着量は CH 1 より CG 0 の方が大きいことから, CH 1 は

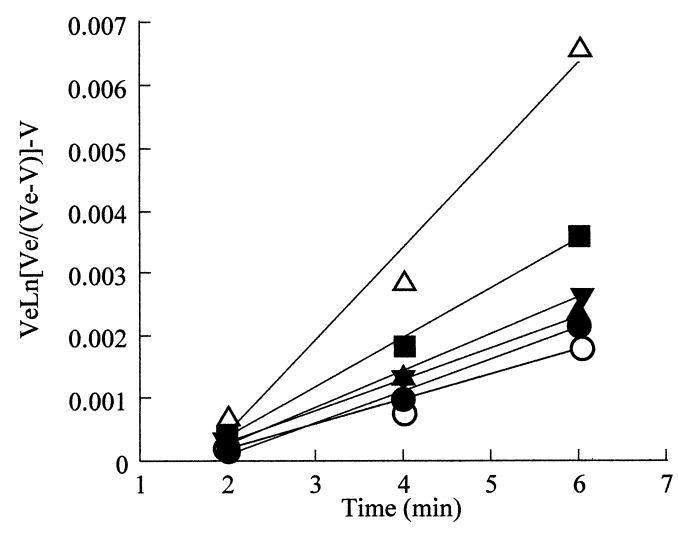

Fig. 6 Sameshima plots of adsorption data of formaldehyde onto carbonaceous materials. $\mathrm{O} 330(5 \%), \boldsymbol{\Delta}$ : S $310(5 \%), \mathbf{\square}$ : S 310 (10\%), $\boldsymbol{\nabla}$ : S $310(20 \%), \triangle$ : S $310(40 \%), \mathrm{O}: \mathrm{CH} 1$

Table 4 Adsorption rate constant of formaldehyde onto carbonaceous materials.

\begin{tabular}{lcc}
\hline \multicolumn{1}{c}{ Samples } & $k\left(\times 10^{-3} \mathrm{mg} / \mathrm{g} / \mathrm{min}\right)$ & $\mathrm{r}$ \\
\hline CH 1 & 0.43 & 0.989 \\
CG 0 & 0.01 & 0.998 \\
CG 10 & 0.04 & 0.993 \\
CG 15 & 0.31 & 0.984 \\
CG 20 & 0.24 & 0.992 \\
S 330 (5\%) & 0.51 & 0.991 \\
S 310 (5\%) & 0.51 & 0.996 \\
S 310 (10\%) & 0.78 & 0.997 \\
S 310 (20\%) & 0.59 & 0.996 \\
S 310 $(40 \%)$ & 1.47 & 0.989 \\
\hline
\end{tabular}

速く飽和吸着量に達するが, CG 0 は緩やかに吸着する ことがわかった。これは, マイクロ波照射処理すること により定数 $k$ は増大し, CG 0 をマイクロ波照射するこ とにより炭素含量が高くなり, 細孔容積も大きくなるた めと考えられる。さらに, S 310（5\%）の定数 $k$ は CG 15 の約 1.6 倍, S 310 (40\%) では約 4.7 倍に増大し, シランカップリング剂で表面改質することで吸着速度が 速くなることが明らかになった。つまり, 炭素材料表面 のアミノ基とホルムアルデヒドが化学反応するためと推 察できた。

\section{4. 結論}

コーヒー豆かすは 20 分間マイクロ波照射処理するこ とで, ホルムアルデヒド吸着量を最も増大させることが できた。また，シランカップリング剂により炭素材料表 面にアミノ基を導入し，化学的吸着によるホルムアルデ ヒド除去について検討した結果, シランカップリング剤 の濃度が高いほど有効であることがわかった。以上の結 
果より，コーヒー豆かすをマイクロ波照射処理すること で, 安価な炭素材料の製造が可能であり, さらに, シラ ンカップリング剂で表面にアミノ基を導入することによ りホルムアルデヒドを高効率除去できることが示唆され た。

\section{文献}

1) 松木秀明 : 大気環境学会誌 33, A 19 (1999).

2) 田中 茂, 井口 勝, 山中一夫, 山田知行, 中尾直 人, 橋本芳一：分析化学 36, 12 (1987).

3) 松村年郎, 安藤正典：資源環境対策 31, 13 (1995).

4) 檜山和成：“実例に見る脱臭技術” (工業調查会, 東
京, 1999) p. 256.

5) C.J. Brinker and G.W. Scherer: "Sol-Gel Science, The Physics and Chemistry of Sol-Gel Processing" (Academic Press, New York, 1990).

6) K. Nakanishi, H. Komura, R. Takahashi and N. Soga: Bull. Chem. Soc. Jpn. 67, 1327 (1994).

7) K. Nakanishi and N. Soga: Bull. Chem. Soc. Jpn. 70, 587 (1997).

8) H.P. Bohem and M. Voll: Carbon 8, 227 (1970).

9) H.P. Bohem: Angew. Chem. Int. Ed. 5, 533 (1966).

10) 日本薬学会編：「衛生試験法・注解」(金原出版, 東 京, 1990) p. 110.

11) K. Ogino: Adsorpt. New 4, 4 (1990).

12) J. Sameshima: Bull. Chem. Soc. Jpn. 7, 177 (1932). 